\title{
Potret Lokalisasi Gang Dolly dalam Perspektif Patologi Sosial
}

\author{
Oleh : \\ Akmal Saputra, MA \\ (Dosen Tetap Prodi Sosiologi FISIP-UTU)
}

\begin{abstract}
Prostitution, localization and freesex is a phenomenon that is familiar in the midst of the people of Indonesia, including the case "Gang Dolly" that attracted public attention in the last year. "Gang Dolly" has been established since the Dutch colonial era and the largest in Southeast Asia and one brothel that gets the legality of the government. Gang Dolly is a social problem that can be analyzed in various perspective, one of them is in pathological perspective. The adverse effect of localization "Gang Dolly" is not only felt by men and women but including The children feel the effects, either psychological aspect or others. The cause of women's involvement in prostitution can be caused by social conditions of local communities or pathological conditions that result in individuals becoming pathological, but it is also due to structural dysfunction. Closure "Gang Dolly", mitigation and prevention needs to be done and has been done by the government of the city of Surabaya, the hope is to make the public should be able to re-live human being who is far from pathological conditions and become a religious community.
\end{abstract}

Key words: "Gang Dolly", Pathological Perspektive, localization.

\section{A. Pendahuluan}

Lokalisasi Dolly atau orang-orang menyebutnya dengan istilah Gang Dolly yang terletak di Kota Surabaya, fenomena ini menjadi menarik perhatian banyak kalangan, baik bagi peneliti, akademisi, praktisi sampai pada pengguna jasa Gang Dolly. Gang Dolly dalam sejarah disebutkan bahwa telah ada sejak masa penjajahan Belanda kemudian juga sebagai pusat prostitusi terbesar se-Asia Tenggara. Menurut referensi yang penulis temukan, ada 9.000 lebih wanita tuna susila yang bergabung jadi satu di kawasan Dolly tersebut. Pria hidung belang mulai dari kalangan atas hingga bawah begitu mudah ditemukan di kawasan Dolly. Tidak hanya penduduk lokal, namun wisatawan asing pun tak jarang 
datang ke sini sekadar untuk memuaskan birahinya. (www.merdeka.com, diakses tanggal 24 Oktober 2015). Versi yang lain mengatakan ada sekitar 1.080 pekerja seks komersial (PSK) dan 300 mucikari yang berada di Gang Dolly. Mereka tinggal bersama sekitar 400 warga setempat. (news.liputan6.com, diakses tanggal 24 Oktober 2015)

Tahun yang lalu topik "Gang Dolly" menjadi hangat dibicarakan di media, semenjak ada kebijakan pemerintah kota Surabaya Tri Rismaharini yang akan menutup pusat prostitusi terbesar se-Asia Tenggara. Mulai dari kebijakan pemerintah kota Surabaya hingga upaya-upaya pemberdayaan terhadap mantan wanita tuna susila pasca penutupan "Gang Dolly". Apa yang dilakukan oleh pemerintah tentu tidak terlepas dari pro dan kontra dari masyarakat dan pelaku bisnis. Bagi yang pro terhadap penutupan lokalisasi "Gang Dolly", lokalisasi menjadi muara kasus human trafficking yang kian menjadi akhir-akhir ini sekaligus lokalisasi berbenturan dengan nilai-nilai dan norma-norma agama Islam. Namun bagi yang kontra terhadap penutupan "Gang Dolly", mereka justru menganggap dampak yang muncul adalah akan mematikan perekonomian di wilayah "Gang Dolly" tersebut. Karena berdasarkan informasi yang ada, perputaran uang di "Gang Dolly" dalam satu malam bisa mencapai miliaran rupiah berkisar Rp 1 sampai 2 miliar.

Penulis mencoba mengajak pembaca sejenak untuk memahami bagaimana sejarah berdirinya lokalisasi "Gang Dolly". Lokasi ini awalnya merupakan kompleks pemakaman masyarakat Tionghoa. Sekitar tahun 1966, kawasan itu kemudian dibongkar dan dijadikan permukiman penduduk. Macam ragam kisah mengenai "Gang Dolly" bermunculan. Pada tahun 1967, seorang mantan wanita tuna susila bernama Dolly Khavit yang menikah dengan pelaut Belanda mendirikan rumah pelacuran pertama di jalan yang sekarang bernama Kupang Gunung Timur I. Wisma miliknya antara lain bernama T, Sul, NM, dan MR. Tiga diantara empat wisma itu disewakan pada orang lain. Lokasi "Gang Dolly" ini berada di Kelurahan Putat Jata, Kecamatan Sawahan, Surabaya, Jawa Timur. (Tjahjo Purnomo dan Ashadi Siregar "Dolly: Membedah Dunia Pelacuran Surabaya, Kasus Kompleks Pelacuran Dolly". Grafiti Pers, April 1982. Dalam www.merdeka.com, diakses tanggal 24 Oktober 2015).

Di dalam buku berjudul "Dolly, Kisah Pilu yang Terlewatkan" karya penulis Cornelius Prastya R K dan Adir Darma terbitan Pustaka Pena, Yogyakarta, 2011, dalam http://regional.kompas.com, diakses tanggal 24 
Oktober 2015 disebutkan bahwa Dolly Khavit adalah seseorang sosok perempuan yang tomboi. Dolly Khavit mengawali bisnisnya karena kesepian dan merasa sakit hati akibat ditinggal suaminya yang berprofesi sebagai pelaut. Dolly dikenal sebagai sosok perempuan cantik yang cukup tersohor dan terkenal pada saat itu, walaupun cantik, Dolly merupakan perempuan yang berlagak seperti lelaki. Bahkan disebutkan ia bertransformasi menjadi laki-laki dan menikahi sejumlah perempuan yang kemudian dipekerjakan di rumah bordil yang dikelolanya. Sebab itu, Dolly diceritakan lebih suka dipanggil "papi" daripada "mami", sebagaimana biasanya orang-orang menyebutkan untuk mucikari atau germo. Namun, kecantikannya memang disebut tidak mampu menutup sifat tomboinya. Oleh karena itu, Dolly dinilai bukan hanya sekadar perempuan, melainkan juga seorang pria yang menyukai para perempuan. Kondisi itu membuat usaha wisma milik "Papi Dolly" ini semakin berkembang. Awalnya hanya untuk melayani tentara Belanda, tetapi kemudian pelanggan yang datang makin hari makin ramai.

Dalam perjalanannya, "Gang Dolly" semakin dikenal oleh masyarakat luas mulai dari masyarakat pribumi sampai masyarakat luar negeri. "Gang Dolly" menjadi kekuatan dan pusat perputaran ekonomi bagi masyarakat setempat. Dalam referensi disebutkan terdapat lebih dari 800 wisma, kafe dangdut dan panti pijat plus . Setiap malam sekitar 9.000 lebih penjaja cinta, pelacur di bawah umur, germo, ahli pijat siap menawarkan layanan jasa kepada para pengunjung. "Gang Dolly" juga menjadi pusat perputaran ekonomi bagi pedagang kaki lima, tukang parkir, dan calo prostitusi, pegawai bar dan karoeke, buruh cuci, satpam, petugas kebersihan, tukang becak, supir taksi, pemilik warung kopi. Semua saling berkait menjalin sebuah simbiosis mutualisme atau saling menguntungkan. www.merdeka.com (diakses tanggal 24 Oktober 2015).

Versi cerita yang lain menyebutkan perintis awal prostitusi di kawasan itu bernama Dolly van der Mart, seorang noni Belanda. Namun kontroversi terhadap siapa yang mendirikan "Gang Dolly" bukan menjadi topik dalam tulisan ini, namun penulis mencoba melihat fenomena "Gang Dolly" adalah sebuah permasalahan sosial yang akan di tinjau dari perspektif patologi sosial.

Isu-isu pelacuran bukanlah hal yang baru dalam sejarah kehidupan manusia. Era modernisasi justru persoalan ini semakin berkembang, karena didukung oleh fasilitas yang semakin memadai, alat komunikasi 
yang canggih, sosial media yang semakin berkembang dan informasi begitu cepat untuk diakses. Internet juga menjadi media untuk mengembangkan sayap pelacuran.

Isu "Gang Dolly" yang penulis angkat dalam tulisan ini hanyalah salah satu dari sekian banyak isu-isu pelacuran yang ada di Indonesia. Gang dolly menjadi isu yang menarik untuk diangkat dari perspektif patologi sosial. Gang dolly merupakan masalah sosial dan juga patologi sosial. Pemerintah telah berupaya menanggulangi masalah-masalah sosial, beberapa diantaranya adalah menekan angka human trafficking, melakukan perlindungan terhadap perempuan dan anak-anak sesuai dengan yang diamanahkan oleh Undang-undang yaitu menjamin terhadap kesejahteraan warga negara. Implementasinya kemudian adalah melaksanakan berbagai program-program pemberdayaan masyarakat termasuk perempuan didalamnya. Namun di sisi yang lain pemerintah sebelumnya justru melegalkan pusat pelacuran Gang Dolly. Tentu pusat pelacuran ini sangat berdampak pada psikologis, sosial, budaya dan kesehatan bagi kehidupan masyarakat sekitar dan masyarakat Indonesia pada umumnya.

Berdasarkan latar belakang diatas penulis akan mengupas fenomena Gang Dolly dalam perspektif patologi sosial.

1. Bagaimana perspektif patologi sosial melihat fenomena "Gang Dolly" yang terbesar di Asia Tenggara?

2. Bagaimana treatment untuk pemecahan masalah prostitusi terbesar di Asia Tenggara?

\section{B. Keterlibatan perempuan dalam Praktek Pelacuran}

Masalah pelacuran merupakan isu yang tindak kunjung usai untuk terus dikaji, mulai dari sebab sampai pada dampak dan bagaimana upaya penyelesaiannya. Tentu masalah pelacuran bukan lahir tanpa ada sebab. Beberapa studi yang dilakukan oleh para ahli bahwa ternyata masalah pelacuran bukan hanya persoalan ekonomi dan kemiskinan semata, namun lebih dari itu.

Studi yang dilakukan Truong (1992) dalam Bagong (2011: 166) menyatakan bahwa proses keterlibatan kaum perempuan dalam praktek pelacuran tidak hanya faktor kemiskinan dan faktor ekonomi semata. 
Keterlibatan perempuan dalam praktek pelacuran dapat disebabkan oleh dua faktor, yaitu struktural dan aspek sosial.

Aspek struktural, kondisi patologis individu disebabkan oleh struktural yang tidak seimbang dan berfungsi dengan baik, sehingga individu berpotensi untuk berperilaku menyimpang. Hal ini dapat kita lihat pada fenomena yang ada, bahwa sebenarnya pemerintah dinilai belum benar-benar menyelesaikan masalah pelacuran. Pemerintah masih melegalkan beberapa tempat pelacuran di Indonesia, Sarkem di Yogyakarta, Dolly di Surabaya (sekarang resmi ditutup). Selain itu pemerintah juga dinilai masih belum serius mengurus persoalan pelacuran yang tidak legal, tentunya tempat ini lebih banyak dibandingkan yang legal. Masalah ini tentu berdampak pada kehidupan masyarakat sekitar, individu dan masyarakat menjadi patologis. Selain itu juga persoalan kemiskinan, sistem pendidikan, pengangguran dan akses kedunia pekerjaan yang merupakan akibat dari struktural yaitu kebijakan pemerintah yang tidak berpihak kepada masyarakat. Implikasinya kemudian sebagian perempuan terlibat pada praktek pelacuran. Artinya bahwa aspek struktural dapat menyebabkan individu yang patologis.

Aspek sosial dan lingkungan, kondisi individu patologis disebabkan oleh individu yang tidak mampu menyesuaikan dan bersosialisasi dengan perubahan sosial yang ada, misalnya gaya hidup, arus informasi yang begitu cepat yang mengakibatkan individu-individu berpeluang untuk tidak mampu menyesuaikan dengan kondisi yang ada, sehingga kondisi ini mengakibatkan pada individu-individu untuk berperilaku patologis. Kondisi sosial dan lingkungan yang patologis akan berdampak pada individu-individu.

\section{Dampak Lokalisasi "Gang Dolly"}

Islam sangat melarang pelacuran, surat Al-Isra ayat 32, menyebutkan yang artinya :

"Dan janganlah kamu mendekati zina; sesungguhnya zina itu adalah suatu perbuatan yang keji dan suatu jalan yang buruk". QS. Al-Israa' (17) Ayat 32

Perzinaan dan pelacuran adalah melakukan hubungan intim antara laki-laki dan perempuan diluar ikatan pernikahan, tentunya membawa dampak yang buruk bagi kehidupan manusia

Surat An-Nur Ayat 2, bunyinya 
"Perempuan yang berzina dan laki-laki yang berzina, Maka deralah tiaptiap seorang dari keduanya seratus dali dera, dan janganlah belas kasihan kepada keduanya mencegah kamu untuk (menjalankan) agama Allah, jika kamu beriman kepada Allah, dan hari akhirat, dan hendaklah (pelaksanaan) hukuman mereka disaksikan oleh sekumpulan orang-orang yang beriman". (QS. An-Nur Ayat 2).

Ayat di atas menjelaskan hukuman bagi laki-laki atau perempuan yang berzina dan belum mempunyai istri atau suami. bagi yang telah bersuami atau beristri maka harus dihukum dengan hukum rajam hingga meninggal dunia, banyak hadits shahih yang menerangkan hal itu.

Undang-undang negara melarang praktik germo (pasal 296 KUHP) dan mucikari (pasal 506 KUHP). KUHP 506: Barang siapa yang sebagai mucikari mengambil untung dari perbuatan cabul seorang perempuan, dihukum dengan hukuman kurungan selama-lamanya satu tahun. Namun belum ada Undang-undang pelarangan pelacuran, melakukan relasi seks sebelum pernikahan atau diluar pernikahan (Kartono, 2011: 243)

Patut di apresiasi, lokalisasi Dolly telah resmi ditutup oleh pemerintah kota Surabaya pada tanggal 18 Juni 2014, karena begitu banyak dampak buruk yang dirasakan oleh masyarakat. Namun, cerita kelam gang Dolly tidak akan terhapus begitu saja dari ingatan masyarakat termasuk anak-anak yang tinggal di kawasan lokalisasi Dolly. Perlu penanganan yang serius dan berkelanjutan dari pemerintah kota Surabaya, tentunya harus didukung oleh semua pihak untuk mengembalikan kondisi semula yang patologis menjadi kondisi yang sesuai dengan nilai-nilai dan norma-norma agama Islam.

Berdasarkan data yang dihimpun Pusat Krisis Berbasis Masyarakat (PKBM) Cahaya Mentari yang beroperasi di wilayah Dolly dan Jarak, Ketua PKBM Cahaya Mentari, Mariani Zaenal, menyatakan lokalisasi pelacuran Dolly menyimpan cerita kelam terhadap kehidupan anak-anak, sebagian anak lulusan sekolah dasar sudah akrab dengan kehidupan seks, rokok, dan minuman keras. Perilaku anak-anak dibawah umur itu muncul karena mereka sudah terlalu akrab dengan dunia pelacuran dan sebagian dari mereka juga lahir dari keluarga yang dekat dengan dunia lokalisasi. Anak-anak di lokalisasi Dolly juga mengaku berpacaran dan kerap berganti-ganti pacar. Di gadget mereka, selalu tersimpan gambar atau foto yang berbau porno, bahkan ada anak yang sudah ketagihan melakukan seks setiap hari. Setiap hari mereka disuguhi pemandangan 
dan lingkungan yang tak patut. Hal itulah yang diyakini menjadi penyebab anak-anak dan remaja di sana melakukan perbuatan yang menyimpang atau patologis. Bentuk kasus yang menimpa anak di lokalisasi tujuh tahun terakhir adalah trafficking, kekerasan seks anak, kriminal, dan kasus narkoba. Menurut psikiater dr. Agung Budi Setiawan Sp.KJ., anak-anak yang berada di sekitar lokalisasi pelacuran sangat berpotensi menderita sakit secara kejiwaan(regional.kompas.com, diakses tanggal 24 Oktober 2015), penyebabnya adalah pemandangan dan pola kehidupan yang dilihatnya setiap hari jauh dari nilai-nilai dan normanorma yang kemudian berdampak perkembangan jiwa anak-anak.

Dampak negatif lainnya adalah lokalisasi menjadi pusat perdagangan wanita (women trafficking) dan tidak memanusiakan manusia layaknya manusia, pelanggaran terhadap HAM, narkoba, miras, penularan penyakit kelamin, HIV, AIDS, kriminal, merusak hubungan rumah tangga, gangguan psikis masyarakat dan merusak moral bangsa yang jauh dari nilai-nilai agama Islam, maka dari permasalahan yang sekian banyak di atas perlu penanganan yang serius dari pemerintah kota Surabaya tidak hanya melihat dari aspek ekonomi semata namun pendidikan agama Islam, perbaikan psikis manusianya, sosial dan budaya. Langkah yang telah diambil oleh pemerintah kota surabaya adalah langkah yang bagus untuk memutuskan mata rantai prostitusi dan penyebaran kondisi patologis lainnya.

\section{D. "Gang Dolly" Perspektif Patologi Sosial}

Tulisan ini menganalisis fakta dan gejala-gejala sosial berdasarkan teori-teori patologi sosial yang dikembangkan oleh Soetomo yang merupakan pakar dibidang masalah-masalah sosial dan pembangunan masyarakat dan tidak mengherankan bila kemudian penulis banyak berpedoman pada teori-teori yang dikembangkan oleh Soetomo.

Perspektif patologi sosial merupakan salah satu turunan dari teori struktural fungsional selain ada perspektif disorganisasi sosial dan perilaku menyimpang. Perspektif patologi sosial merupakan perspektif yang paling awal digunakan untuk memahami sekaligus menganalisis masalah-masalah sosial. (Turner 1986: 9 dalam Soetomo, 2008: 75).

Ilmu-ilmu sosial dan budaya merupakan ilmu yang berkembang kemudian setelah sebelumnya telah berkembang ilmu-ilmu alam, oleh karena itu tidak mengherankan apabila kemudian banyak teori-teori ilmu 
sosial yang sangat dipengaruhi oleh ilmu-ilmu alam. Ilmu pengetahuan secara umum kita temui terbagi pada tiga bagian yaitu ilmu alam, ilmu sosial dan ilmu humaniora. Jika kita membaca teori-teori sosiologi, teoriteori mereka banyak dipengaruhi oleh ilmu-ilmu alam, seperti Herbert Spencer yang memperkenal teori analogi organik yang mengibaratkan masyarakat seperti tubuh manusia, apabila satu sistem saja mengalami masalah maka akan mempengaruhi sistem-sistem yang lain, begitu juga dengan masyarakat, apabila satu sistem bermasalah maka akan mempengaruhi kepada sistem-sistem lain yang ada dimasyarakat.

Berdasarkan uraian diatas, maka patologi juga merupakan istilah pinjaman atau adopsi dari ilmu alam khususnya ilmu yang berhubungan dengan kesehatan, yang berarti ilmu yang mempelajari tentang penyakit. Sedangkan sosial bermakna sesuatu yang berhubungan dengan masyarakat atau gejala-gejala sosial. Oleh karena demikian patologi sosial adalah ilmu yang mempelajari tentang penyakit masyarakat, salah satunya adalah kasus Gang Dolly yang sedang dianalisis dalam tulisan ini.

Patologi sosial dalam menganalis masalah-masalah sosial juga meminjam istilah diagnosa seperti layaknya diagnosa yang digunakan oleh seorang dokter dalam mengobati pasien yang sedang sakit. Soetomo membagi tiga tahapan dalam menganalisis dan memecahkan masalahmasalah sosial, yang pertama: identifikasi masalah, diagnosa masalah dan yang terakhir adalah treatment atau upaya pemecahan masalah. hal ini jelas sekali seperti seorang dokter yang mengindentifikasi penyakit kemudian mendiagnosa penyakit dan kemudian treatment atau pemberian obat yang tepat agar penyakit mudah-mudahan dapat sembuh dan pasien dapat hidup kembali secara normal, begitu juga kalau diibaratkan dengan masyarakat, harapannya masyarakat dapat kembali hidup selayaknya manusia.

Jika kita melihat kasus Gang Dolly maka langkah yang kita lakukan adalah mengindentifikasi terlebih dahulu masalah yang terjadi di Gang Dolly, yang terlihat jelas adalah tersedianya tempat pelacuran yang legal, namun tentu masalah tidak hanya satu, artinya pelacuran akan berdampak pada masalah-masalah sosial yang lain seperti perdagangan manusia, narkoba, miras, penipuan, pelecehan seksual, lesbian, penyimpangan seksual (misalnya dorongan seks untuk melakukan dengan anak-anak), kemudian langkah yang kedua yang dilakukan 
adalah mendiagnosa penyebab kenapa masalah tersebut bisa terjadi dan kemudian apa penyebab utamanya, tentunya kalau sudah benar pada tahap diagnosa maka pada tahap treatment akan lebih tepat upaya pemecahan masalahnya.

Patologi sosial juga mendiagnosis masalah sosial dari kegagalan masyarakat dalam menyesuaikan dengan perkembangan dan perubahan sosial yang ada, perubahan sosial terus terjadi akibat dari era globalisasi, informasi semakin mudah di dapat dan diakses termasuk media online dan media cetak, gaya hidup masyarakat semakin berkembang, kemiskinan meningkat, pengangguran meningkat, lapangan kerja menjadi sempit. Masalah sosial ini yang kemudian individu berperilaku pada kondisi yang patologis. Dalam perspektif ini melihat masyarakat yang sehat dan baik adalah yang mampu mewujudkan social adjusment, sedangkan masyarakat dikatakan sakit atau patologis apabila terjadi kondisi sebaliknya yaitu kondisi social maladjusment (Soetomo, 2008: 8081).

Perubahan sosial masyarakat akan terus terjadi, karena pada dasarnya manusia sebagai anggota masyarakat adalah makhluk yang dinamis yang terus berubah sesuai dengan perkembangan zaman, manusia bukanlah makhluk yang statis. Oleh karena demikian apabila manusia tidak mampu masuk dan menyesuaikan dengan perubahan sosial yang ada, maka kemudian akan digilas oleh perkembangan zaman, artinya masyarakat akan cenderung melakukan tindakan-tindakan yang menyimpang.

Gillin dalam Soetomo (2008: 82) Patologi sosial merupakan kondisi masyarakat yang maladjusment. Kondisi yang maladjusment kemudian berdampak pada kelangsungan hidup suatu kelompok sosial yaitu mengakibatkan ikatan sosial dan tatanan kehidupan mereka menjadi terganggu.

Maladjusment atau kondisi yang tidak diharapkan dapat dianalisis melalui dua level yaitu: level individu, level kelompok atau masyarakat. Pada level individu, apabila individu tidak mampu menyesuaikan dirinya dengan perkembangan dan perubahan yang ada. Level kelompok atau masyarakat, apabila tidak mampu menyesuaikan antar unsur dalam sistem sosial yang ada. Tetapi dalam kehidupan bermasyarakat dapat terjadi hubungan saling mempengaruhi antara maladjusment pada level 
individu dengan maladjusment level kelompok atau masyarakat atau dapat dikatakan adanya hubungan timbal balik dari berbagai level. Apabila dominan individu anggota kelompok/masyarakat yang mengalami maladjusment, maka sangat berpeluang terjadinya kehidupan masyarakat yang patologis. Sebaliknya kondisi kehidupan masyarakat yang social maladjusment sangat berpeluang menumbuhkan kondisi serupa. Berdasarkan pandangan ini, treatment yang harus dilakukan menciptakan kembali kondisi yang adjusment baik pada kehidupan individu maupun kelompok dan masyarakat. (Soetomo, 2008: 82).

Berdasarkan penjelasan teori diatas, maka sebenarnya dalam proses sosial atau proses kehidupan masyarakat akan selalu terjadi saling mempengaruhi, kondisi individu-individu berpengaruh pada tatanan kehidupan masyarakat, begitu juga sebalik kondisi sosial masyarakat juga akan berpengaruh pada kehidupan individu-individu.

Auguste Comte mengibaratkan masyarakat sebagai organisme hidup, hal ini seperti yang telah penulis sebutkan sebelumnya yang bahwa ilmu-ilmu sosial cenderung dipengaruhi oleh ilmu-ilmu alam. Berdasarkan anggapan bahwa masyarakat sebagai organisme hidup, maka teori-teori sosial kemudian dibangun berdasarkan analogi antara human society dan human body keduanya sering disebut vast organisme (Julian, 1986: 12 dalam Soetomo, 2008: 75).

Berangkat dari teori yang dijelaskan oleh Auguste Comte, masyarakat diibaratkan dengan organisme hidup, namun sebenarnya tidak dapat diibaratkan sepenuhnya demikian, tentu saja memiliki perbedaan-perbedaan diantara organisme dengan sistem sosial. Pada sistem organisme, bagian-bagian tersebut saling terkait dalam hubungan yang sangat erat dan terlihat jelas, sedangkan dalam sistem sosial hubungan yang sangat erat dan dekat kurang jelas terlihat. (Soetomo, 2008: 76-77)

Berdasarkan analogi human society (sistem sosial) dengan human body (sistem organisme biologis), masalah sosial terjadi apabila individu atau institusi sosial tidak berhasil menyesuaikan dengan perubahan sosial yang terjadi, oleh karena itu berdampak pada bekerjanya organisme sosial. Kondisi yang seperti ini individu atau institusi sosial dikatakan dalam keadaan sakit atau patologis. (Poloma, 1987: 25 dalam Soetomo, 2008: 77). 
Berdasarkan kajian teori diatas, jika kemudian kita melihat kasus yang ada, masalah lokalisasi Gang Dolly merupakan salah satu bentuk ketidak-siapan individu dalam menghadapi perubahan di era globalisasi yang begitu cepat, apakah itu masalah ekonomi, kemiskinan, pengangguran, gaya hidup, sehingga individu kemudian terlibat ke dalam berbagai tindakan yang menyimpang, salah satunya praktek pelacuran. Ketidak-beraturan dan tidak berfungsinya sistem sosial dan institusi sosial yang ada akan melahirkan kondisi individu-individu yang patologis. Begitu juga sebaliknya, ketidak-beraturan dan tidak berfungsinya sistem sosial dan institusi sosial juga dipengaruhi oleh individu-individu yang patologis.

\section{Perspektif patologi sosial "awal"}

Berdasarkan uraian tersebut diatas, prinsip analogi yang digunakan dalam perspektif patologi sosial cenderung menggunakan medical model dalam memecahkan masalah sosial beserta segala implikasinya, yaitu identifikasi masalah, diagnosa masalah dan treatment. (Soetomo, 2008: 77-78).

Menurut perspektif patologi sosial "awal", bahwa perspektif ini cenderung membuat diagnosa bahwa individu merupakan sumber masalah dalam kehidupan masyarakat. Masalah sosial muncul akibat dari individu tidak mampu masuk dalam proses sosialisasi atau individu bersikap dan berperilaku yang tidak berpedoman pada nilai-nilai sosial dan norma-norma yang ada dalam masyarakat. Dalam perspektif patologi sosial, nilai-nilai sosial, moral dan humanitarian yang menjadi pedoman dalam kehidupan bermasyarakat. (Soetomo, 2008: 78).

\section{Pemecahan masalah}

\section{Isolasi Individu}

Berdasarkan anggapan bahwa individu merupakan sumber masalah maka kemudian pemecahan masalah sosial harus dilakukan agar tidak terjadi proses pewarisan kondisi patologis kepada individu-individu yang lain. Treatment yang dilakukan dengan cara memisahkan atau mengisolasi individu yang berperilaku patologis dari berbagai interaksi sosial dan bahkan dapat mengisolasikan dan memasukkannya kedalam penjara dengan tujuan agar penyakitnya tidak menular pada individu 
yang lain. Penularan tersebut dapat terjadi melalui proses interaksi sosial dan komunikasi. (Soetomo, 2008: 78).

Berdasarkan treatment isolasi individu dalam perspektif patologi sosial "awal", individu merupakan sumber masalah, individu bersikap dan berperilaku tidak sesuai dengan nilai-nilai dan tatanan sosial yang ada. Maka kemudian individu yang berada di lokalisasi Dolly harus segera diisolasi agar tidak terjadi penyebaran perilaku menyimpang ke individu-individu yang lain.

\section{Resosialisasi}

Upaya pemecahan dengan cara yang lain adalah dengan proses resosialisasi individu, yaitu suatu proses untuk mendorong individu yang patologis tersebut agar siap dan mampu untuk berperilaku sesuai aturan dan nilai-nilai sosial, artinya pemecahan masalah dilakukan fokus pada perubahan aspek moral individu. Upaya pemecahan masalah melalui resosialisasi adalah menganggap sistem beserta aturan-aturannya dianggap benar, artinya masalah-masalah sosial yang muncul bukan karena kesalahan sistem tetapi justru kesalahan individu dalam melaksanakannya. (Soetomo, 2008: 78-79).

Pada kasus "Gang Dolly", resosialisasi dapat dilakukan dengan melakukan pembinaan moral kepada wanita tuna susila, mantan wanita tuna susila dan masyarakat umum lainnya baik laki-laki maupun perempuan termasuk anak-anak melalui pendidikan moral, bagi yang muslim pendidikan dan pemahaman agama Islam harus ditingkatkan kualitasnya, dengan tujuan agar masyarakat tidak terjerumus kembali kejalan yang patologis. Sebenarnya hukum atau aturan-aturan sudah jelas, bahwa prostitusi adalah sebuah bentuk perilaku yang patologis, namun individu sendiri tidak melaksanakan dan mematuhi hukum atau aturanaturan yang ada. namun dalam analisis lain ternyata ada sistem yang bermasalah sehingga masyarakat berpeluang untuk melakukan perilaku yang patologis, artinya Gang Dolly sebelum ditutup merupakan praktek prostitusi yang diakui oleh negara.

Pada kasus Gang Dolly sebelum ditutup secara resmi, sebenarnya resosialisasi telah pernah dilakukan oleh pengurus Muhammadiyah Daerah Surabaya untuk pembinaan moral termasuk bagi wanita tuna susila. (www.sangpencerah.com, di akses tanggal 14 Juli 2014). 


\section{Perspektif patologi sosial "baru"}

Perspektif patologi sosial "baru" ini mendiagnosa masalah dengan melihat cacat yang ada dalam masyarakat dan institusi sosialnya, artinya perspektif ini melihat cacat individual merupakan akibat sistem yang bermasalah dengan asumsi bahwa masyarakat yang tidak bermoral akan menghasilkan individu yang tidak bermoral. Perilaku patologis merupakan dampak dari sistem yang patologis. Pendekatan dalam diagnosis masalah inilah yang kemudian membedakan perspektif patologi sosial lama dan baru. Perspektif patologi sosial lama mencari sumber masalah dari individu, sedangkan perspektif patologi sosial baru mencarinya dari sistem. (Soetomo, 2008: 79-80).

Melihat fenomena Gang Dolly telah terjadi kecacatan pada institusi sosialnya dan cacat pada sistem/kebijakan pemerintah. Cacat institusi sosial akibat dari cacat pada sistem/kebijakan pemerintah, artinya masyarakat yang terlibat dalam prostitusi Gang Dolly akibat dari pemerintah yang telah melegalkan praktek prostitusi pada saat itu. Kemudian cacat individu diakibatkan oleh cacat institusi sosial dan sistem/kebijakan pemerintah. Masyarakat yang terlibat dalam prostitusi Gang Dolly akan mempengaruhi perilaku individu-individu yang ada, artinya masyarakat yang tidak bermoral akan menjadikan individu yang tidak bermoral juga.

\section{Pemecahan masalah}

Berikut ini beberapa masukan dan solusi memecahkan masalah lokalisasi "Gang Dolly" berdasarkan perspektif patologi sosial "baru" yang mencari sumber masalah dari sistem yang patologis:

a. Penyempurnaan perundang-undangan mengenai larangan terhadap pelacuran, melakukan relasi seks sebelum pernikahan atau diluar pernikahan, lokalisasi, pornoaksi dan pornografi

b. Memperkuat hukum adat masyarakat

c. Kebijakan-kebijakan pemerintah yang pro terhadap masyarakat

d. Membuka lapangan kerja bagi masyarakat dan peningkatan skill serta dijalankannya program-program pemberdayaan melalui bantuan modal usaha

e. Pendidikan bagi masyarakat perlu ditingkatkan, bagi yang muslim pendidikan agama perlu ditingkatkan misalnya pengajian, 
kurikulum agama Islam perlu ditingkatkan di sekolah dan perguruan tinggi

f. Perlu pembentukan tim anti terhadap berbagai bentuk pelacuran. Tim ini di fasilitasi oleh pemerintah dengan memanfaatkan potensi lokal masyarakat

g. Evaluasi dan monitoring menjadi penting untuk mengukur keberhasilan/efektifitas/efisien terhadap program-program yang akan dijalankan dalam rangka menekan praktek prostitusi.

\section{E. Penutup}

Prostitusi, pelacuran, lokalisasi apapun nama dan bentuknya tetaplah tindakan yang patologis yang melanggar norma-norma dan nilainilai agama Islam, adat dan budaya bangsa Indonesia. Oleh karena itu, penanggulangan atau penanganan terhadap kondisi ini perlu dilakukan dengan serius, berkelanjutan dan didukung oleh semua pihak termasuk penyempurnaan atau perubahan terhadap undang-undang yang belum memuat larangan terhadap pelacuran atau prostitusi, demi terciptanya masyarakat yang agamis dan jauh dari kondisi yang patologis.

\section{DAFTAR PUSTAKA}

\section{Buku dan Jurnal}

Jurnal, Masyarakat, Kebudayaan dan Politik, 2011, Airlangga University Press. Surabaya. Volume 25, Nomor 3, Juli-September 2012. ISSN 2086-7050

Jurnal PMI, Media Pemikiran dan Pengembangan Masyarakat, 2009, Fakultas Dakwah UIN Sunan Kali Jaga

Kartono, Kartini, Patologi Sosial, 2011, Rajawali Press, Jakarta

Soetomo, Masalah Sosial dan Upaya Pemecahannya, 2008, Pustaka Pelajar, Yogyakarta

Soetomo, Pembangunan Masyarakat Merangkai sebuah Kerangka, 2009, Pustaka Pelajar, Yogyakarta

\section{Website}


Community: Volume 1, nomor 1, Oktober 2015

http://news.liputan6.com, Dilematisnya Penutupan Gang Dolly. Di akses tanggal 24 Oktober 2015

http://regional.kompas.com, Anak-anak di Dolly Akrab dengan Seks, Rokok dan Miras. Di akses tanggal 24 Oktober 2015

http://regional.kompas.com, Anak-anak di sekitar Kompleks Pelacuran Berpotensi Sakit Jiwa. Di akses tanggal 24 Oktober 2015

http://regional.kompas.com, Ini Asal-usul Nama Gang Dolly. Di akses tanggal 24 Oktober 2015

http://www.merdeka.com. Sejarah Gang Dolly sampai Terbesar di Asia Tenggara. Di akses tanggal 24 Oktober 2015

http://www.sangpencerah.com, Muhammadiyah: PSK Dolly Mau Tobat Tapi Mengalami Intimidasi Preman. Di akses tanggal 24 Oktober 2015 